\title{
Sensory Receptor of the Ear
}

National Cancer Institute

\section{Source}

National Cancer Institute. Sensory Receptor of the Ear. NCI Thesaurus. Code C33532.

The six patches of hair cells in the membranous labyrinth located in the receptor organs

of the inner ear, including the organ of corti, the macula of the utricle, the macula of the saccule, and the ampullary crest in each of the three semicircular canals. 